\title{
On Not Being Porn: Intimacy and the Sexually Explicit Art Film
}

\section{ABSTRACT}

Since the mid-twentieth century, we have passed from a time where sexual frankness was actively obstructed by censorship and industry self-regulation to an age when pornography is circulated freely and is fairly ubiquitous on the Internet. Attitudes to sexually explicit material have accordingly changed a great deal in this time, but more at the level of the grounds on which it is objected to rather than through a general acceptance of it in the public sphere. Critical objections now tend to be political or aesthetic in nature rather than moralistic. Commercial cinema still seems wary of a frank exploration of sexuality, preferring to address it tangentially in genres such as the erotic thriller. In Europe, an art house canon of sexually explicit movies has formed, starting with Bertolucci's Last Tango in Paris (1972) and the French-produced In the Realm of the Senses (1976). This article looks at the steps taken since the 1970s to challenge out-of-date taboos and yet at the same time differentiate the serious film about sex from both pornography (operating in parallel with mainstream cinema but in its shadow) and the exploitation film. After reviewing the art film's relationship with both hard and soft core, two recent films, Intimacy (2000) and 9 Songs (2005), are analyzed for their explicit content and for the way they articulate their ideas about sex through graphic depictions of sexual acts. Compulsive and/or claustrophobic unsimulated sexual behaviour is used as a way of asking probing questions of intimacy (and its filmability). This is shown to be a very different thing from the highly visual and staged satisfactions of pornography.

\section{Abstract}


Cinema, understood as a form of mass public entertainment, has had a very vexed relationship with sexuality. It has consistently failed to address issues in sexual behaviour and its range of possible meanings because of a generally hostile censorship climate. That climate has been predicated on the general prevalence of patrician moral values and anxiety about social taboos. The dominant American studios have not wanted to alienate powerful moral and religious lobbies or to produce products which in any way jeopardized their access to large and heterogeneous audiences. This led historically to the industry's adoption of the Production Code from 1930 onwards, a set of voluntarily-entered-into constraints in many domains but particularly in the field of sexuality, which engendered a striking lack of frankness in these matters, what Linda Williams calls "the long adolescence of American movies" (Hard Core 21). Perhaps symbolic of this anxiety is the ubiquity of twin beds in films representing the lives of married couples. It can and should be observed that film-makers became very adept at the art of suggestion to deal with and overcome these often mind-numbing constraints. But one of the few areas where indirection and subtlety were not to much avail was in the film addressing sexual mores and the complexity of physical relations.

A second order of problem for this type of film was the challenge represented by the pornographic film industry. Living in the shadows for the first half of the twentieth century, the porn industry gained immensely from libertarian movements and the slackening of social taboos. However, the public maintenance since then of strictures on explicitness has to some extent created the niche in which it operates. Explicitness is pornography's answer to the problem of authenticity of desire:

Hard core desires assurance that it is witnessing not the voluntary performance of feminine pleasure, but its involuntary confession. The woman's ability to fake the orgasm that the man can never fake (at least according to certain standards of evidence) seems to be at the root of all the genre's attempts to solicit what it can never be sure of: the outof-control confession of pleasure, a hard core "frenzy of the visible." (Williams, Hard Core 50)

Williams's imperative, "the frenzy of the visible," but applying to both sexes, crossed over into the mainstream, because the same anxiety about the nature of desire applied there too. Pressure to reform no longer tenable codes of what might constitute "the visible" was building, in the form of 
Kinsey (1948 and 1953), ${ }^{1}$ Masters and Johnson (1966), ${ }^{2}$ the Playboy Organization, American stag and nudie flicks and the European cinema avantgarde. The years 1970-73 are often considered a watershed for American cinema, when films flaunting their explicit violent and sexual content broke into the national distribution system and attracted large mixed audiences. From a strictly commercial point of view, audiences were significant but not industry-changing. By the mid-1970s, America had reverted back to a generally more middle-of-the-road set of film-making practices. However, first the home-entertainment revolution in the 1980s and then the explosion of the Internet in the 1990s made the question of access to sexually explicit material no longer essentially a question of censorship and public morality, but rather one of consumer choice. Censors began to lose confidence in their mission and to concentrate on protecting children, since the defence of public morals, as evidenced by efforts to regulate the preferences and activities of private citizens, was felt to have become unmanageable. So, the question is raised in Linda Williams's edited collection Porn Studies (2004), what new forms of explicit material have now emerged and where the serious film of sexual exploration can go in the age of ubiquitous porn. There can scarcely be a computer-possessing person who has not stumbled upon caches of this material, both commercialized and amateur selfexhibitionist. It is difficult to register the same levels of shock and outrage as when the sight of full frontal nudity or scenes of sexual congress were rare and/or only the result of strenuous searching or much expenditure. Deregulation of media industries has thrown up multiple channels for the dissemination of sexually explicit material (including occasionally the serious film about sex). This has helped to muddy some already murky water. The validity of distinctions here is problematic, since, given the heat which attends this debate, many interest groups do not tend to adopt a nuanced approach to the subject; even when they do, distinctions appear arbitrary.

1 Alfred C. Kinsey and his team of researchers at the University of Indiana produced two seminal studies, Sexual Behavior in the Human Male (1948) and Sexual Behavior in the Human Female (1953), collectively popularized as the Kinsey Report, which enlarged understanding of sexual conduct in the general American population and had the effect of normalizing and legitimizing a lot of behaviour considered taboo. Kinsey's research methods were largely based on extensive interviewing.

2 William H. Masters and Virginia E. Johnson were sexologists at Washington University, St Louis, who carried on the work of Kinsey by concentrating on the psychological and physiological aspects of sexual behaviour. Their two main publications were Human Sexual Response (1966) and Human Sexual Inadequacy (1970). In tune with the greater latitude of their times, their 1957-65 research was observational and consisted of arbitrarily pairing sexually active men and women under laboratory conditions. Their results shed a great deal of light on many physiological aspects of sexual intercourse and masturbation. 
Discriminating the film about sex from pornography and from the exploitation film (one using sex but not fundamentally about sex) has insisted on a number of quite unworkable distinctions between what is arousing (porn/exploitation) and what is not (the art film). The other charge levelled at the art film about sex, that it is intellectually pretentious, is also subjective. The writings of Georges Bataille, and analyses of his ideas by intellectuals like Roland Barthes and Susan Sontag, are often cited in this context. Like Bataille's work, such films have been identified as controversial, have aroused extreme critical reactions and have been dismissed as both preposterous and sick. One thing is clear, however. The grounds for attacking or rejecting these works have been shifting over the last forty years. Moral revulsion has largely given way to aesthetic, philosophical and political objections.

The film which was first to respond to the new censorship climate internationally was Bernardo Bertolucci's Last Tango in Paris (1972). Indeed, according to Lewis (194-95), 1972 was the pivotal year for the breakthrough of sexually explicit material into the mainstream, being also the year of Deep Throat, Deliverance and A Clockwork Orange. In many respects, Last Tango is a benchmark for all the art films about sex that followed (not that, numerically speaking, many did follow). An essential feature is a certain concentration on the heterosexual couple and on the degree of impersonality and intensity that attends their coupling. Most attention has been given to the explicitness of this film's sex acts when in fact they are not at all explicit. Instead, the film makes specific reference to a variety of acts (notably sodomy) by speech and context and then suggests them by simulation. But by focusing on the variety of acts, and making their execution dramatically meaningful, the film was laying a claim to being exploratory rather than exploitative. Looked at from this side of the pornography explosion, the film can be seen to be rather coy. It does not attempt parity of male and female nudity, for example. Except for one scene, Brando is fully clothed throughout. Maria Schneider, on the other hand, is seen on camera fully and partially naked for entire scenes. Brando's presence confers prestige on the production, making a statement that the sex is performance, enactment. It also has an unbalancing effect of making Schneider, the twenty-year-old actress playing Jeanne, both his professional and his erotic subordinate. Brando's Paul establishes and enforces the rules of the tryst, exclusively out of his own needs, until the moment late on in the film when he chooses to abandon them.

Another benchmark element is the film's Frenchness-its Parisian locations, its use of the French language, its louche social settings and more relaxed social values. Paul manages a cheap hotel or flophouse, which is home to a variety of addicts, musicians and whores. These figures, amongst 
whom we find Paul's wife's lover, establish an ambience of bohemianism. Frenchness is a filter for Anglo-Saxon audiences for the film's unconventional attitudes to sex. Paul meets Jeanne when they happen to see an empty apartment at the same time. This apartment becomes the locus for their first animalistic coming together, and for subsequent meet-ups. The bareness of the setting is metonymic of the elemental nature of the encounter of male and female. It is de rigeur that the location and the preliminaries of sex are not aestheticized, although the film equivocates on this somewhat with the casting and decorative wardrobe of Maria Schneider.

A third benchmark feature is psychological damage. It is axiomatic that you cannot break through to the sorts of discoveries in sex that these films seek unless you are lifted out of the plane of bourgeois normality. Paul is deeply traumatized by the suicide of his wife Rosa, whose body still remains laid out in one of his hotel rooms. The heavily theatrical scene in which he berates and apologizes to the corpse is one of the film's rawest. There is a suggestion that Paul was as emotionally closed before his wife's suicide as he is after, but this is a minor note in the film's philosophy of sex. Psychological damage is the conduit by which you can come to understand the essential identity of eros and thanatos. Paul schools Jeanne in the need for degradation before there can be understanding. This takes the form of bodily violations and fantasies of exposure to filth and bestiality. In this respect, a clear demarcation is established between the pretensions to pleasure and recreation and revelation of pornography and the quest for knowledge and understanding (always obscure and occluded) in the art house sex film, which is almost without exception grim in tone. A consistent but not invariable feature of the genre is the drive towards death itself, where one partner kills or is coerced into killing the other. Extreme, excessive or obsessional sexual behaviour is thereby represented as a kind of suicide, and Brando seems at the end to goad Schneider into shooting him.

Another product of 1970 s liberalism which manages to establish a credible separation between itself and porn is Oshima Nagisa's Ai no korida (In the Realm of the Senses) of 1976. This is odd for two reasons. The iconoclast in Oshima was not at all offended by the ascription of the term pornography to his film; in his desire to attack a range of Japanese taboos, he positively welcomed it. Secondly, although it contains perhaps the most disturbing and graphic content, it is in many respects the least glum of the art house sex films. The fact that it is set in Japan in the 1930s, in a culture which has very different expectations of sexual relations than we are used to, creates a significant distancing effect for Western audiences. Its effect on Eastern audiences is harder to gauge because it was banned outright in Oshima's native Japan (and has since been the object of zealous censorship). Although shot there, it was edited in Paris and 
is for all practical purposes a French film, enjoying a long and successful run in Parisian cinemas in 1976. Another important difference is that although the main story concerns the obsessive sexual relationship of a pair of lovers, they are not monogamous and sexual activity is very far from being a private affair. One of the film's shocks is the extent to which the love-making goes on under the gaze of a number of other persons, nor is that gaze necessarily the prurient one of voyeurism. The domestic arrangements in a house with small rooms and paper sliding doors mean that very little is secretive; indeed the sway which Kichi holds over his household is such that he does not have to apologize for or explain his sexual appetites. Indeed, the erotic seems much more integrated with the social in this world. His fancy eventually settles on Sada, who becomes drawn into a jealous and increasingly passionate tryst. Sada, as a servant courtesan, is herself relatively liberated and responds to Kichi's requests for ever more outré sexual experiences. These eventually build to games of erotic asphyxiation in order to heighten and prolong sexual pleasure and lead to Sada's strangulation of Kichi. One of the factors that facilitated acceptance of the film was its being based upon a well-reported case from the period. Unlike Jeanne's killing of Paul, it is the mutually desired end of a relationship that can have no other outcome. The film contextualizes the lovers' sensuality by implicit comparison with grotesque images of ageing and debility. And in another scene, the most discordant in a film of many startling images, we see Kichi walking apprehensively down a street in 1937 when massed lines of Japanese troops are heading in the other direction. Clearly he opts for a personal erotic suicide over the militaristic collective suicide that the scene clearly anticipates.

Aesthetically, as Linda Williams argues, Ai no korida draws much inspiration from Japanese Shunga, woodcut engravings of erotic scenes from the eighteenth and early-nineteenth centuries (Screening Sex 190-97). Sexual intercourse is clearly visible in both the woodcuts and Oshima's film, and there is no disavowal of the intention to arouse. As I suggested earlier, most defences against obscenity laws, as they have been applied to film production and exhibition, rest precisely on denial of an artwork's tendency to arouse. The key differentiation from pornography here would seem to be the disinclination to pander to the desire to see all. Acts take place clothed, semi-naked and naked, from a variety of angles, some of which facilitate voyeurism and others do not. The camera reveals or withholds according to principles which do not obey the rigid dictates of "the frenzy of the visible." Body positions seem haphazard, unexpected, and sometimes awkward. Nor is clothing and drapery used according to the artful contrivance of soft core. Maureen Turim makes this same point in the context of general observations about the performative elements of sex in the film: 
In the scene early in the film in which Sada is presented as having sex with Kichi while she plays the samisen, Realm of the Senses does not separate sex from music, dance and theater. It stages the sounds, gestures, and rhythms of sex as the equivalents of these other performances, capable of being blended with them.

This simply extends a visual metaphor present throughout the film in which the kimono acts as a theatrical curtain whose drapes can be drawn to reveal the sexual organs as the actors in the spectacle. (Turim 130)

Sada begins the film as the more passive of the partners but she is always associated with a certain wildness. She is introduced rejecting the advances of a fellow servant and then engaging in a public brawl with her. During the flirtation and courtship phase of the relationship with Kichi, she is frequently seen bearing a knife. As she becomes the more active of the sexual partners, so she asserts her desire for gratification in more forceful ways. Turim records that the film is usually read as progressive in its "liberating female desire" but notes that Sada becomes more subtly demonic as the film reaches its climax, when the knife is used to castrate her dead lover (139). At no point is what happens less than consensual. However, Oshima appears to want to suggest that sexual exploration is not without deadly risk. The alternative to ecstatic self-extinction is slow decrepitude, and another strong point of contrast with conventional pornography is the presence in the film of old people as desiring but dysfunctional sexual beings. Sada meets an old man who asks her to arouse him but without result, and later she sleeps with a client who cannot achieve coitus and so asks to be struck as a means to stimulation. Kichi has sex with two women much older than himself, in the second case, as it were, experimentally, with Sada watching. This confirms to them the eventual futility of their sexual project, the maintenance of high and ever improving erotic satisfactions. Sado-masochism is at first an aid to sexual stimulation, then a desperate remedy and finally a welcome exit strategy. It is a datum of the sexually exploratory art film that no state of equilibrium or harmony between male and female can be reached.

Ai no korida has only been screened in expurgated versions in Japan. It suffered a similar chequered fate at the 1977 New York Film Festival, when it had to be pulled from the programme after New York Customs threatened to impound all copies as imported obscenity (Williams, Screening Sex 189). Litigation and counter-litigation followed before a victory of sorts was reached. It was allowed to be screened, significantly, at the New York Museum of Modern Art, and then more widely at selected venues in major US cities. It was never submitted to the MPAA and so was left to award itself an " $\mathrm{X}$ " rating. 
A Supreme Court judgment in America in June 1973, Millerv. California, brought to an abrupt end the brief convergence of the pornographic and the adult-themed film (Williams, Screening Sex 260-65). The court confirmed an individual state's right to enforce stricter rules against obscenity than those applied by the federal judiciary. Few studios thereafter would risk prosecutions or bans on films given anything more severe than an " $\mathrm{R}$-restricted" rating. Sexually explicit films were either confined to the " $\mathrm{X}$ " rating and thus marketed as pornography to restricted audiences, or they were re-edited to receive an "R," or they were by definition made outside the USA and had to take their chance with the notoriously censorious CARA (Code and Rating Administration) of the Motion Picture Association of America. I would argue that the Home Entertainment revolution beginning in the early 1980s, led by video, DVD and cable channel networks, defused the loaded issue of public licensing. Straight-to-video and straight-to-cable sexually explicit filmed narratives did not have to meet public morality criteria because they were sold or rented directly to customers or delivered to subscribers only. Rating restrictions applied only to new films that went on general release. In a long overdue upgrading of the system, the MPAA introduced an "NC-17" rating (No children 17 or under to be admitted) in October 1990, to distinguish the adultthemed film from the X-rated porn film. The strategy backfired, however, for advertizers refused to carry promotion for such films which they still identified as "dirty," Blockbuster declined to stock them and so producers strove as keenly to avoid them as they had to avoid "X" ratings. This rating was given, for example, to critically successful and serious films The Cook, The Thief, His Wife and Her Lover and Henry: Portrait of a Serial Killer (both 1989). The first film to receive an NC-17 rating was the October 1990 release Henry and June, Philip Kaufman's story of Henry Miller's sexual adventures in Paris. Although about pioneers in sexual exploration, it was the avant-garde of at least two generations earlier and did not aspire to the degree of explicitness of many other films, and so failed to engage audiences. For the industry, in any event, the fundamental issue had become not moral but economic: did anyone want to make a film that would not be available to the crucial 13-17 age demographic? When Kubrick's Eyes Wide Shut (1999), Verhoeven's Showgirls (1995) and, most absurdly of all, South Park: Bigger, Longer and Uncut (1999) fell foul of the NC-17 rating, it was clear that no one knew what it was for anymore.

It is worth while looking briefly at two films which attempted to make adult-themed cinema within the rating-regulated commercial system, Kaufman's Henry and June and Schrader's The Comfort of Strangers (both 1990). Henry and June is set in Paris like Last Tango and in the 1930s like Ai no korida. But there the resemblances end. Henry and June betrays 
its kinship with the contemporaneous soft-core productions of Zalman King (91/2 Weeks, Wild Orchid and Red Shoe Diary). It is technically soft too, with lush music, pretty close-ups, costumes and compositions, artful fades concluding love scenes and a rhetoric of desire articulated through lascivious looks and reaction shots. Sex is frequent but it is subordinated to its two principals' (Henry Miller and Anaïs Nin) supposed creativity ("writers are just hungry for experience, they steal everything," says June). Dialogue is hackneyed, of the "Be careful, Anaiis, abnormal pleasures kill the taste for normal ones" kind; the final voice-over might have come from the Emanuelle soft-core franchise ("I wept because the process by which I had become a woman was painful") and declarations of love are much commoner than in the art film about sex genre. Art films about sex do not mention love much, any more than they are about the travails of marriage. Most unconvincing of all are the film's clichés of Parisian eroticism: the brothel scenes, the risque paintings and cabarets, the connived-at affairs. Self-consciously naughtier, it is nevertheless tonally closer to Minnelli's An American in Paris (1951) than it is to Bertolucci's Last Tango; Kaufman's is a Paris where Parisians either speak English or, lovable bohemians that they are, do not speak at all.

In terms of its explicitness (some nudity and some simulated sex), The Comfort of Strangers deserves its "R" rating. Much of the film takes place in holiday mode in ravishing Venetian settings. But the core of the movie is tougher, more probing, than Henry and June. A young couple find a new intimacy triggered in their flagging relationship after a chance encounter with an older Venetian couple who are addicted to sado-masochist practices in the bedroom. The young couple interrupt their sight-seeing to take to their hotel room and seem to turn into lovers in a French art house movie: experimenting sexually, discussing their orgasms, and "muttering ... stories that produced moans and giggles of hopeless abandon, that won from the spellbound listener consent to a lifetime of subjection and humiliation” (McEwan 81). Schrader's film, which overlays McEwan's book with Armani style, is nonetheless true to his vision of violence opening the doors to intimacy. Colin and Mary are both progressive liberals; Robert and Caroline, whom they meet, are both predatory biological essentialists. McEwan therefore makes a direct association between heterosexual sexual passion and a latent but "structural" pathological imbalance between men and women. This is the "knowledge" that the surviving partner Mary takes from her experience, and which she tries unsuccessfully to communicate to her dead lover in a mortuary.

She was in the mood for explanation, she was going to speak to Colin.... tell him her theory, tentative at this stage, of course, which explained how 
the imagination, the sexual imagination, men's ancient dreams of hurting, and women's of being hurt, embodied and declared a powerful single organising principle, which distorted all relations, all truth. But she explained nothing, for a stranger had arranged Colin's hair the wrong way. She combed it with her fingers and said nothing at all. (McEwan 125)

It still remains a little enigmatic why the liberals succumb; after four days of delight and total immersion in one another in their hotel room, they return to Robert's home to sacrifice Colin to his murderous erotic urges.

Most of the films mentioned in this article are notorious but have been little seen by general audiences. Asked what they think is the most sexually daring of mainstream movie genres, most would point to the erotic thriller, of which there have been dozens made in the 1980s and 1990s. Indeed, films like Fatal Attraction (1987) and Basic Instinct (1992) have reached such wide audiences that they are deemed significant for the commentaries they offer on gender relations, the threat of AIDS and homophobia. But with the fleeting exception of the famous "bare crotch" shot from Basic Instinct, films so conspicuously about sexual desire are wary of being explicit about it. What they offer instead is full, or partial, female nudity. The American market is open to graphic violence but remains coy about sexual behaviour. William Friedkin, the director of many controversial films including Cruising (1980) and Jade (1998), when asked about the likeness of the latter film to Bunuel's Belle de Jour and whether it could have been made without the crime plot replied:

Yeah, sure. But the change would have meant that it would not have gotten made, except as a French movie (laughs) ... Jade had to be masked as a crime melodrama, with the secret life of a woman as the background. It would only get made in America as a crime melodrama, as a thriller. It would not get made if it was just a pure examination of a woman's sexuality. (140)

In the erotic thriller, excessive or exploratory sexual behaviour is positioned as a sub-set of violent behaviour; once it is pathologized, it can be brought within a moral framework and resolved by crime-and-punishment plot trajectories. These plots seek to tidy and discipline the unruly aspects of such conduct. There is an implicit pathology within the arthouse sexually-explicit film but it is not ultimately moralistic. The resolution of these films is melancholy, defeatist, but not retributional. This is why Comfort of Strangers is more art-house film in disguise than erotic thriller.

The examples chosen thus far are perhaps enough to show that the focus guiding these art-house explorations of sexuality is a searching 
interrogation of heterosexual intimacy. Radical feminist cinema, like that of Catharine Breillat, in her Romance (1999) or Anatomy of Hell (2004), affirms that at the present time this is just not possible between men and women. However, more liberal approaches such as we find in the last two films discussed below still want to cling to this possibility, even if they are not optimistic about the outcome. These are Patrice Chéreau's Intimacy (2000) and Michael Winterbottom's 9 Songs (2005). It is important, however, to distinguish between the ideological and intellectual work which a film does and the buzz and marketing around it. These films have both suffered from too much commentary about the sexually explicit film arriving in Britain, and about actors and actresses having real sex with each other. I would prefer to stress how, like Tango with its metaphor of dance and Realm of the Senses with its referencing of a range of Japanese performance arts, both films foreground sex as performance as well. Intimacy manages a running commentary on acting and the theatre alongside its investigation of anonymous sex. 9 Songs punctuates a love affair from pick-up to break-up with the practice of concert attending. Their common point seems to be, both in form and content, that both types of performance be raw, naked and authentic, not just acting in the conventional sense. We know enough about the stop-go process of movie-making, and the onsite presence of crews, whether they be mainstream or grindhouse, to doubt whether onscreen intimacy is achievable. Indeed the whole enterprise seems to hinge on the connotations of those two words: "intimacy" as both a synonym for the closest possible understanding and/or fellow-feeling between two human beings and as a euphemism for sex, and "act," as in "to do or to execute" (in for example "the sexual act") and as in "to simulate or fake" a feeling or a behaviour. I would argue that a powerful artistic desire to over-ride the inauthenticity of "acting," the euphemistic aspect of "intimacy," drives these sexually explicit films.

But, leaving aside the hype about who did what to whom, what that is new emerges from these two post-millennial films? The first thing to notice is that neither has any truck with death. The sex-to-extinction motif seems to have been dropped. One is tempted to observe that the reason for this is that both films are at least partly British. Intimacy has been called "Last Tango in Lewisham" (Falcon 20) because it is read to some extent as a French film made in London, set in Mike Leigh-type locations with a grungy aesthetic and casting Leigh alter-ego Timothy Spall in a major role. The source text for Intimacy is the Hanif Kureishi novella of the same name, spliced together with one of his short stories, "Nightlight." Although these works are in the territory of the unfaithful husband and his dalliances with other women, they sadly ruminate on what is lost when the family is broken up, particularly in respect of a father's relations with 
his children. This is only a background in the film, which focuses on the intensity of an ongoing afternoon affair with an unknown woman during which only minimal communication takes place. It has the same presupposition as Last Tango, that in a sense all that matters is in the room with them, is in the sex itself. This premise breaks down in the middle of the film however, as Jay begins to stalk his mystery lover; he finds he needs that extra-sexual information. His investigations continue and he begins to obtrude himself into her family life, disturbing it and trying to break it up. This only succeeds in making everyone, already unhappy, even unhappier. The affair terminates at the point where Jay demands (and gets) an explanation from Claire for her conduct. Jay's bitterness and provocation make his behaviour seem like acts of revenge. Naturally, some have read the film as deeply misogynistic, as wilfully misrepresenting the nature of female sexuality in order to castigate it. In other words, Jay leaves his wife and kids, is unhappy about the situation he has engineered for himself and so proceeds to destroy the marriage of a woman who has accepted him on the only terms he offers. Jay is a head bartender and his lover Claire is an unsuccessful actress and teacher of acting. Her behaviour is explained to some extent by her need to rekindle the well-springs of her feeling so that she can perform better. The film equivocates on whether her behaviour is just another unconvincing performance, a willed rather than a felt act. Her relationship with Andy (Spall as her husband) is unsatisfactory because he is conventionally supportive, but when the affair comes to light, he takes the opportunity to tell her what a lousy actress she is and always has been. Ironically, Andy seeks out Jay to tell him that he loves his wife more and more each day, one of the film's few uses of the word "love."

Reaction to the film has mostly been to the sex scenes. Outrage at the film's philosophy seems displaced onto its settings. In particular, the sordid squat in which Jay lives falls well below the barren but chic apartment in Tango-one critic remarked that the film's dishonesty is most manifest in denying what would be Claire's more primal desire to tidy this basement flat up. Other critics have suggested that its commitment to impersonal sex is more characteristic of the lifestyle of gay artists like Patrice Chéreau himself. Indeed Chéreau and his screenwriter have interpolated a gay French bartender, Ian, into the plot to comment on Jay's prevarications. On the sex itself, commentary has been skewed and unkind, about the body types of Mark Rylance and Kerry Fox as Jay and Claire (he too thinset, she too thick-set), when all that this betrays is the extent to which pornography's representation of sex is dominated by the stereotypes of the buffed and sculpted body. The second line of attack is brutishness. Even more than in Tango, the sex is a preamble-less collision of bodies, without ceremony and followed by Claire's hasty departure. Neither protagonist 
offers a credo for what they are doing on Wednesday afternoons and neither seems to understand it very well. Sex starts in awkwardness and finishes in confusion. There are seven sex scenes in all, most of them intense but relatively brief. One is a flashback to Jay masturbating during the final stages of his marriage. Another is with a young girl he picks up, who never stops chattering and whom he cannot wait to leave. The others are with Claire. Most of them entail full nudity and leave little doubt that both principals are performing in both senses of the word. However, this is passion born of need, not the pursuit of pleasure. It fully meets the condition of art-house sex, since it is clearly grim and uncompanionable. It seems both protagonists doubt their ability to feel. As Wednesday afternoons falter, explanations are sought and Jay accuses Claire thus in a showdown in her changing-room:

At some point, just to make it very clear where I'm coming from, at one point I thought if what we did together was all that you wanted, it was because you knew more than me. I thought you had found something. I thought you were ahead of me, and that in the end you would tell me what you knew. That was the really great thing. That at some fucking point in the future, you would tell me what you knew. And of course you just keep your gob shut.

Sexual intercourse is therefore a form of arcane knowledge, a type of immersion, the meaning and mutuality of which may only be communicated retrospectively. Claire of course has only a hazy idea what this is and seems to need the sex to rediscover her own authenticity for professional reasons. At the end, when they meet in the squat, now stripped for Jay's departure, he implores her to stay with him in what is a declaration of love in all but name, but she declines. They then make love fully clothed, against a wall, exactly as in the first coming together of Last Tango, a clear homage to that film but also a statement that this film finishes where the other one starts. It resembles Realm of the Senses in its use of other partners, confidantes and onlookers (barman Ian, druggy friend Victor, Claire's actress friend Betty and Andy, of course) to round out and critique the social consequences of their solipsistic behaviour. The gloomy Mike Leigh milieu and many London street scenes ground the film in the story of a man who has unhappily left his wife having an affair with a woman who unhappily won't leave her husband, denying it the doom-laden resonance of these earlier films. The film has, it seems, been harshly attacked from both sides. It was banal for some and pretentious for others. It remains possible, however, to believe that Jay and Claire have achieved a state of intimacy, but that the baggage from their earlier lives has made the survival 
of that intimacy problematic. It is possible because their "performances" are naked and strong.

Intimacy has a soundtrack of bleak and alienated British pop and rock from the 1990s, dominated by David Bowie's “sarf” London drawl. 9 Songs is melancholy but it is not miserabilist. The reason for this is, I believe, because although the story is narrated after the affair is already over, the male protagonist is young and the story is therefore subsumed within an implicitly longer narrative of growing and learning and resigned acceptance, rather than the existential mid-life crises that characterize the experiences of men in most of the other films discussed here. 9 Songs uses music not to overlay narrative with emotion, as movies do, but to space out and signpost the lives of its principals with cultural events. Kieron O'Brien's Matt meets Margo Stilley's Lisa at a gig at the Brixton Academy. They have sex immediately afterwards and their relationship begins. It is an avowedly small and experimental film (at sixty-six minutes, this is the shortest of what is often a long-drawn-out genre). Winterbottom says (DVD interview) that he had made previous relationship stories without the sex; now he wanted to tell the story exclusively through the sex, something that perhaps Cronenberg is trying to do in Crash (1997). O'Brien and Stilley spent a day in a hotel room with a camera crew getting used to each other's bodies before any commitments were made or any shooting schedules drawn up. In the absence of a script, difficult and demanding sex scenes were broken up with long days spent filming concerts around London. In all, some one hundred and fifty songs were recorded on camera, of which only nine made it into the finished film.

Winterbottom does not expose the relationship to pressures or temptations from without; once again, all that is essential is in the room with them and present in the sex. Far from investing in the idea of mutual obsession, this film takes the view that there is always asymmetry in relationships. Matt's early voiceover characterization of Lisa as "21, beautiful, egotistical, careless and crazy" is therefore ominous. If Matt has the authorial position, Lisa is more dominant in the bedroom. She is more sexually pro-active and adventurous than him, and what begins in pleasure and mutuality shifts towards the more inscrutable nature of Lisa's desires. Matt risks the word "love" but Lisa does not reciprocate. Lisa shows signs of boredom and irritation after the third concert. After the fourth, Matt initiates an erotic bondage game, which she takes over and turns to her own purposes and which becomes increasingly masturbatory. After song five, it is clear she harbours some resentment towards him. Lisa is fully involved in a visit to a lap-dance club while Matt seems somewhat removed from the goings-on. We later see her alone on the bed using a dildo. Matt contemplates the scene for a while and then retreats. This is not just 
another long drawn out break-up film, however. Matt attends concert six on his own, and then they have their only brief row in the film, over her use of prescription drugs, but shortly afterwards they are shown making love with renewed vigour. In a film of explicit sex acts, the fellatio and ejaculation scenes are graphic but edited to avoid the climactic rhythms of pornography.

The piano music of Michael Nyman, at the eighth concert, precedes her announcement that she is leaving to go back to America and what constitutes the last sex scene of the film. At the beginning of the film, Matt had casually asked her if they would ever make love without a condom; she replied no. We therefore duly see the last act of penetration, the condom still in place, because it symbolizes Lisa's control over events. There is only the faintest hint of an instability in Lisa, but her wildness is indissociable from her allure. We learn that until the day of her departure, she has never let Matt visit her flat. Ultimately, we (and Matt) find her nature unreadable: every orifice of her body has been explored by Matt (and the camera) yet her nature remains occluded, private. The sex acts themselves finally remain unrevealing, they are opaque, they fail to define the state of the relationship-we cannot discriminate sexual abandonment from consolation or pity sex, if that is indeed what is going on. In that sense, 9 Songs enacts the detachment of sex from emotional commitment or economic and social manoeuvrings, two domains in which it often operates in narrative cinema. The film posits a state of post-intimacy, beyond sex. Matt's familiarity with her body leads to neither possession nor knowledge. His lack of progress is symbolized by the ninth song, "Love Burns," sung by the same performers as the first, Black Rebel Motorcycle Club. Lisa's privacy is more represented by her inviolable apartment and her unshared friends than by her body, which she has readily shared. 9 Songs demystifies and materializes sex as a social practice, putting it alongside the many acts of eating, drinking, drug-taking, dancing and concert-going which constitute normal, even mundane, behaviour. It singularly fails to ascribe to it the redemptive or transcendental features, or the will to those features, that we find in most art-house treatments.

Instead the film naturalizes the stages of loss of affect. It is assisted in this by the film's other metaphor, apart from song. Matt is a polar scientist and his work takes him to the Antarctic wastes. Metaphors of blankness and coldness are laid over the functioning relationship, as well as during its demise. Over images of Matt snowshoeing over a hill in Antarctica, he says of the place: "Claustrophobia and agoraphobia in the same place, like two people in a bed." Later on, relationships are likened to icebergs. When attached to the icecap, they trap for perpetuity the climatic record of all lived human history; once detached, they take just two weeks to melt in open 
sea. This detachment is the enemy of all intimacy. The art-house film looks to find intimacy in confinement to and absorption in the physical act itself. But, discovering themselves thwarted by a natural abatement of sexual desire, even in the face of multiple and ingenious techniques of arousal, or by its unavoidable dilution in life's other social claims, our sexual pioneers have been driven towards death. More recently, however, a moody shrug is all they can manage. Nothing much has been learnt or seems "knowable" from sex in these films; their achievement is partly to show that they have no time for the clearly false gratifications of pornography.

\section{Works CiTED}

Ai no korida [In the Realm of the Senses]. Dir. Nagisa Oshima. Screenplay by Nagisa Oshima. Perf. Tatsuya Fuji, Eiko Matsuda. Argos Films, 1976. Film.

Bataille, Georges. Erotism: Death and Sensuality. Trans. Mary Dalwood. San Francisco: City Lights, 1962. Print.

The Comfort of Strangers. Dir. Paul Schrader. Screenplay by Harold Pinter. Perf. Christopher Walken, Rupert Everett, Helen Mirren, Natasha Richardson. Erre Produzioni/Sovereign Pictures, 1990. Film.

Falcon, Richard. "The Limits of Sex.” Rev. of Intimacy, dir. Patrice Chéreau. Sight and Sound 11.7 (2001): 20-24. Print.

Friedkin, William. Interview by Linda Ruth Williams. The Erotic Thriller in Contemporary Cinema. Ed. Linda Ruth Williams. Edinburgh: Edinburgh UP, 2005. 134-42. Print.

Henry and June. Dir. Philip Kaufman. Screenplay by Philip Kaufman. Perf. Fred Ward, Maria de Medeiros, Uma Thurman. Universal, 1990. Film. Intimacy. Dir. Patrice Chéreau. Screenplay by Patrice Chéreau and AnneLouise Trividic. Perf. Mark Rylance, Kerry Fox, Timothy Spall. Studio Canal, 2001. Film.

Kureishi, Hanif. Intimacy. London: Faber, 1998. Print.

---. "Nightlight." Love in a Blue Time. New York: Scribner, 1997. Print.

Last Tango in Paris. Dir. Bernardo Bertolucci. Screenplay by Bernardo

Bertolucci and Franco Arcalli. Perf. Marlon Brando, Maria Schneider. United Artists, 1972. Film.

Lewis, Jon. Hollywood v. Hard Core: How the Struggle over Censorship Saved the Modern Film Industry. New York: New York UP. Print.

McEwan, Ian. The Comfort of Strangers. London: Picador, 1982. Print.

9 Songs. Dir. Michael Winterbottom. Screenplay by Michael Winterbottom. Perf. Kieran O’Brien, Margo Stilley. Revolution Films, 2005. Film. 
Turim, Maureen. The Films of Oshima Nagisa: Images of a Japanese Iconoclast. Berkeley, CA: U of California P, 1998. Print.

Williams, Linda. Hard Core: Power, Pleasure, and the "Frenzy of the Visible". London: Pandora, 1990. Print.

---. Screening Sex. Durham: Duke UP, 2008. Print.

---. ed. Porn Studies. Durham: Duke UP, 2004. Print. 